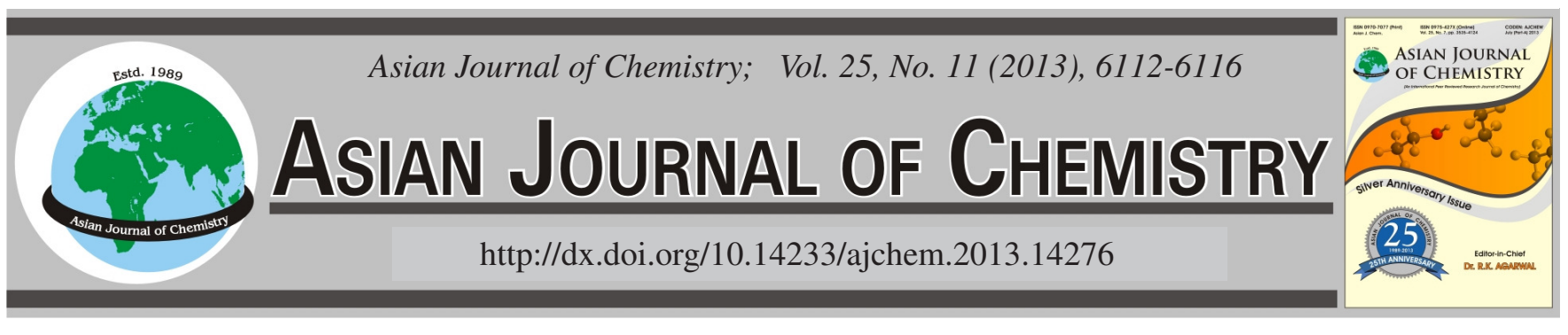

\title{
Activated Zeolites and Heteropolyacids: An Efficient Catalysts for the Synthesis of Triacetoxyaromatic Precursors of Hydroxyquinones
}

\author{
DOKARi HadjILA* and Hammadi MoHAmed
}

Faculty of Sciences, University of Boumerdes, 35000 Boumerdes, Algeria

*Corresponding author: Fax: +213 24816284; Tel: +213 792037937; E-mail: hadjila_2@yahoo.fr

(Received: 7 July 2012;

Accepted: 29 April 2013)

AJC-13414

The Thiele-Winter reaction is of interest for synthesis of triacetoxyaromatic precursors of hydroquinones. Liquid acid such as, chlorosulfonic acid and solid acids like heteropolyacids have an efficient catalyst can effectively replace sulfuric acid in acetoxylation reaction of quinones without use of organic solvent at room temperature.

Key Words: Heteropolyacids, Actived zeolites without solvent, Hydroxynaphthoquinones.

\section{INTRODUCTION}

The hydroxynaphthoquinones ${ }^{1}$ are well known substances for their chemical and biological properties ${ }^{2}$. The hydroxynaphthoquinones like phthiocol ${ }^{3}$, lawsone ${ }^{4}$, juglone ${ }^{5}$, menadione and atovaquone ${ }^{6}$, have gained large interest due to their presence in natural products and their pharmacological properties as antitumoral, antiprotozoal, antiinflammatory, antiviral and antifungal ${ }^{7}$.

We have used this methodology to prepare the acetoxylation reactions of quinones and naphthoquinones acid-catalyzed by $\mathrm{ClSO}_{3} \mathrm{H}(\mathrm{Ho}=-13.80)$ and heteropolyacids $\mathrm{H}_{3} \mathrm{PW}_{12} \mathrm{O}_{40}(\mathrm{Ho}=-13.6)$, in the absence of solvent at room temperature.

Our attention has focused on the use of metallic phthalocyanines supported in the oxidative reactions of naphthotriols prepared from the Thiele-Winter reaction in order to synthesize hydroxynaphthoquinones natural products having antibiotic properties. The acetoxylation reaction of juglone, menadione and lawsone with acetic anhydride catalyzed by sulfuric acid ${ }^{8,9}$, (Ho $=-11.94)$, at room temperature is slow with low yields especially in the presence of substituents on the naphthoquinone as electron donors. Sulfuric acid was replaced by chlorozincique acid $^{10}$ and tetrafluoroboric acid ${ }^{1}$ with low yields.

To overcome this problem where the acidity of the medium thus protonation of the quinone is the decisive step, we opted for the use of liquid hyperacid more acidic than sulfuric acid in homogeneous conditions such as chlorosulfonic acid: $\mathrm{ClSO}_{3} \mathrm{H}^{11}(\mathrm{Ho}=-13.80)$ and solid superacid as heterogeneous conditions in the heteropolyacid: $\mathrm{H}_{3} \mathrm{PW}_{12} \mathrm{O}_{40}(\mathrm{Ho}=$ -13.6). In our work we are particularly interested in the synthesis of 2,5-dihydroxy-1,4-naphthoquinone (3b). This synthesis involves first the oxidation of 1,5-dihydroxynaphthalene in product (3) and its transformation into tetracetoxy (3a) by Thiele-winter reaction. The saponification of (3a) followed by catalytic oxidation in situ of naphthotriols. (Scheme-I).

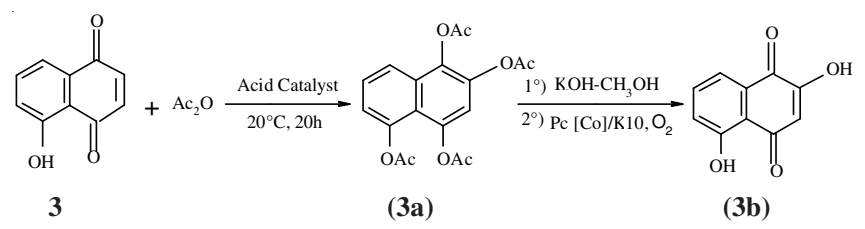

Scheme-I: Synthesis of 2,5-dihydroxy-1,4-naphthoquinone (3b) from juglone

\section{EXPERIMENTAL}

Melting points (m.p.) were determined with a Kofler hot apparatus and are uncorrected. Proton NMR spectra (PMR) were determined on Brucker AC 250 (250 MHz, $\mathrm{CDCl}_{3}$, $\mathrm{Me}_{4} \mathrm{Si}$ ). The IR spectra were recorded as $\mathrm{KBr}$ pellets on Perkin Elmer 16 PC FT-IR spectrometer UV-visible spectra $\left[\lambda_{\max }\right.$ $\log (\varepsilon)]$ were obtained with spectrophotometer Perkin-Elmer Lamda-15.

Microwave irradiation were carried out with a commercial microwave oven (Toschiba ER 7620) at $2450 \mathrm{MHz}$. and with resonance cavity TEo13, joined to a generator MES 73-800 of microwaves. Masse spectra were carried out on a Nermag Riber R10; TLC analyses were performed by using Kieselgel Schleicher and Shull F 1500 Ls 254 and Merck 60 F 254. The grinding of products were carried out on a analytical grinder A 10 of Janke and Kenkel-IKA Labortechnik. The montmorillonite K10 was obtained from the firm of Sûd Chemie. 
Zeolites (ZSM-5, DAY) as ammonium form wer calcinatd at $500{ }^{\circ} \mathrm{C}$ under dry flow before use. (firm BDH). Heteropolyacids were commercially avaible from Fluka.

\section{Phthalocyanine (Co) Supported on K10}

Preparation of montmorillonite K10 exchanged by $\mathrm{Co}^{2+}$ : In a $250 \mathrm{~mL}$ flask, the montmorillonite K10 (20 g) was added to a solution of $\mathrm{CoCl}_{2}(0.2 \mathrm{~mol})$ dissolved in $100 \mathrm{~mL}$ of distilled water. The reaction al mixture was stirred for $24 \mathrm{~h}$ at room temperature. The suspension was washed twice with distilled water then centrifuged. The montmorillonite exchanged by $\mathrm{Co}^{2+}$ was washed with methanol and re-centrifuged. The solid was dried for $24 \mathrm{~h}$ in vacuum then finely ground. The final product was a clear beige colour.

Phthalocyanine intercalated in the montmorillonite K10: A solution of phthalonitrile ( $20 \mathrm{mmol} ; 2.56 \mathrm{~g}$ ) dissolved in $20 \mathrm{~mL}$ of dichloromethane was added the solid montmorillonite K10 (5 g) exchanged with some metallic cations $\left(\mathrm{Co}^{2+}\right)$. After contact for $2 \mathrm{~h}$, the remaining liquid was evaporated under reduced pressure. The activation of the solid under microwaves irradiation: $p=$ power, $t=$ time of irradiation) was carried out in a resonance cavity. After cooling, the solid was successively washed with water, acetone $(20 \mathrm{~mL})$ and then with dichloromethane $(20 \mathrm{~mL})$. The solid was dried under reduced pressure and the extracted with acetonitrile as a solvent using a Soxhlet for $8 \mathrm{~h}$. Catalysts were characterized by FTIR, electronic spectra of metalated phthalocyanine intercalated into montmorillonite was very close to those observed with pure metalated phthalocyanine, but the bands were shifted.

Preparation of zeolites exchanged $\mathbf{H}^{+}$: $10 \mathrm{~g}$ of zeolite (ZSM5 or DAY) are placed in a $50 \mathrm{~mL}$ flask and then treated with a solution of $\mathrm{NH}_{4} \mathrm{Cl}(0.1 \mathrm{M})$ previously prepared with deionized water. The stoppered flask is allowed to stand overnight at room temperature. The solid residue was recovered by filtration and then activated in a muffle furnace at $500{ }^{\circ} \mathrm{C}$ for $24 \mathrm{~h}$. The zeolite in $\mathrm{H}^{+}\left(\mathrm{H}^{+}\right.$-ZSM5 or $\mathrm{H}^{+}$-DAY) is stored in a dry container.

Preparation of hydroquinones: In a typical experiment, the phenol $(100 \mathrm{mmL})$ was dissolved in $200 \mathrm{~mL}$ of $10 \%$ solution of sodium hydroxide under stirring at room temperature. A saturated aqueous solution of sodium persulfate $(100 \mathrm{~mL})$; $23.8 \mathrm{~g}$ ) was slowly and carefully added for $3 \mathrm{~h}$. At the end of the addition, stirring was maintained at room temperature. The mixture was stand over-night. The solution acidified with Congo red and was extracted twice with ether. The aqueous layer was treated with an excess of hydrochloric acid and warmed in a steam bath for $0.5 \mathrm{~h}$. After cooling, it was once, dried on magnesium sulphate and finally distilled to afford the corresponding hydroquinone.

Oxidation to quinones: In a typical experiment, a current of air was passed through à $U$ tube fitted with a filter flask. The tube contains the supported phthalocyanine $(0.1 \mathrm{~g})$ in suspension in a solution of hydroquinone $(5 \mathrm{mmol})$ dissolved in $10 \mathrm{~mL}$ of a mixture of dioxane/water $(60: 40)$ for $6 \mathrm{~h}$ at room temperature. The oxidation of hydroquinone was followed by TLC. After disappearance of hydroquinone, the solution was filtered and evaporated under vacuum. The quinones were purified by chromatography on silicagel or by sublimation. All products are known compounds and were identified by comparaison of their physical and spectral data with those of authentic samples. The UV spectral of quinones was carried out in water-dioxane mixture.

Acetoxylation reaction under homogeneous conditions (liquid acids): In a typical experiment, $10 \mathrm{mmol}$ of juglone was dissolved in acetic anhydride $(0.2 \mathrm{~mol}) .5 \mathrm{mmol}$ of catalyst was added and the mixture was stirred at room temperature. After $20 \mathrm{~h}$ the mixture was stirred at room temperature. The solution was poured on ice and after the ice melted the mixture was filtered and the solid 1, 2, 4, 5-tetracetoxynaphthalene, produce (3a) was crystallized in ethanol.

Acetoxylation reaction under heterogeneous conditions (solid acids): In a typical experiment, $10 \mathrm{mmol}$ of juglone was dissolved in acetic anhydride $(0.2 \mathrm{~mol} ; 21.64 \mathrm{~g})$.

$1 \mathrm{~g}$ of catalyst was added and the mixture was stirred at room temperature. After $48 \mathrm{~h}$, the products were separated by chromatography on a silica column eluted successfully with ethyl acetate/cyclohexane (10/90). The different fractions gave respectively a yellow solid (unreacted quinone) and a beige solid (1, 2, 4, 5-tetracetoxynaphthalene) (3a). It must be noted that traces of products of diacetylation could be detected by thin layer chromatography.

The acid solids e.g., zeolites and hetero-polyacids have been tested in this study and the results are reported in Table- 2 .

Saponification and oxidation in situ: In a typical experiment, a current of air was passed through à U tube fitted with a filter flask. The tube contains the [Pc (Mn)/K10 (0.1 $\mathrm{g})$ ] in suspension in a solution of product (4) $(0.6 \mathrm{~g})$ dissolved in $\mathrm{CH}_{3} \mathrm{OH}(20 \mathrm{~mL})$ and $\mathrm{KOH}(2 \mathrm{~g})$ for $6 \mathrm{~h}$ at room temperature. After filtration and evaporation of the methanol, the product (5) was crystallized.

(Pc [CO] supported on K10): Purple solid, m.p. $>300^{\circ} \mathrm{C}$ $\mathrm{MO}$; microwaves irradiation resonance cavity. $(\mathrm{P}=630 \mathrm{~W}, \mathrm{t}=$ $10 \mathrm{~min}) ; \mathrm{C}_{32} \mathrm{H}_{16} \mathrm{CoN}_{8}$; Yields: $85 \%$ UV-visible $\lambda_{\max } \log (\varepsilon) /$ (1-chloronaphthalene) nm : 669.5 (4.42); 642.1 (3.88); 604.2 (3.78); 580.1 (3.22); IR (KBr, $\left.v_{\max }, \mathrm{cm}^{-1}\right): 1636,1522,1400$, 1044, 870, 796, 756, 532, 525, 466.

2-Methyl-1,4-benzoquinone (2a): Brown solid, yields: $95 \%$, m.p: $72-73^{\circ}$ (lit. $\left.73^{\circ} \mathrm{C}\right)^{12} ; \mathrm{C}_{7} \mathrm{H}_{6} \mathrm{O}_{2}$, calcd. $\mathrm{H} 4.95 \% \mathrm{C}$ $68.85 \%$, Found: H $4.87 \%$ C $68.73 \%$; UV-visible $\lambda_{\max } \log (\varepsilon)$ (dioxane $/ \mathrm{H}_{2} \mathrm{O}$ ) nm: 278.2 (4.15), 312.3 (2.75), 422.6 (1.31); NMR ${ }^{1} \mathrm{H}\left(\mathrm{CDCl}_{3}\right) \delta: 2.01\left(\mathrm{~s}, 1 \mathrm{H}, \mathrm{CH}_{3}\right) ; 6.23(\mathrm{~s}, 1 \mathrm{H}) ; 6.52(\mathrm{~m}$, $1 \mathrm{H}), 6.85(\mathrm{~d}, 2 \mathrm{H})$; IR $\left(\mathrm{KBr}, \mathrm{v}_{\max }, \mathrm{cm}^{-1}\right): 1689(\gamma \mathrm{C}=\mathrm{O})$.

2,6-Dimethyl-1,4-benzoquinone (2b): Brown solid, yield: $90 \%$, m.p.: $73-74^{\circ} \mathrm{C}$ (lit. $71-73^{\circ} \mathrm{C}$ ) ${ }^{13} ; \mathrm{C}_{8} \mathrm{H}_{8} \mathrm{O}_{2}$, calcd. $\mathrm{H}$ $5.92 \%$ C $70.58 \%$, Found: H $6.01 \%$ C $70.50 \%$; UV-visible $\lambda_{\max } \log (\varepsilon)\left(\right.$ dioxane $\left./ \mathrm{H}_{2} \mathrm{O}\right) \mathrm{nm}: 270.6$ (4.29), 318.1 (2.52), 414, 3 (1.25); IR ( $\left.\mathrm{KBr}, v_{\max }, \mathrm{cm}^{-1}\right): 1685(\gamma \mathrm{C}=\mathrm{O})$.

2,6-Dimethoxy-1,4-benzoquinone (2c): Brown solid, yield: $89 \%$, m.p.: $253^{\circ} \mathrm{C} ; \mathrm{C}_{8} \mathrm{H}_{8} \mathrm{O}_{4}$, calcd. $\mathrm{H} 4.80 \% \mathrm{C} 57.14 \%$, Found: $\mathrm{H} 4.87 \%$ C $57.12 \%$; UV-visible $\lambda_{\max } \log (\varepsilon)$ (dioxane/ $\mathrm{H}_{2} \mathrm{O}$ ) nm: 279.5 (4.25), 379 (2.69), 465.5 (0.45); IR (KBr, $\left.v_{\max }, \mathrm{cm}^{-1}\right): 1678(\gamma \mathrm{C}=\mathrm{O})$.

5-Hydroxy-1,4-naphthoquinone: (Juglone) (3): Red solid, Yield: $87 \%$, m.p.: $159-160{ }^{\circ} \mathrm{C}$ (lit. $\left.161^{\circ} \mathrm{C}\right)^{13} ; \mathrm{C}_{10} \mathrm{H}_{6} \mathrm{O}_{3}$, calcd. H $3.47 \%$ C $68.97 \%$, Found: H $3.58 \%$ C $68.92 \%$; UVvisible $\lambda_{\max } \log (\varepsilon)$ (dioxane/ $\left.\mathrm{H}_{2} \mathrm{O}\right) \mathrm{nm}: 249.3$ (4.21), 331.1 (3.18), 422.1 (2.98); $\mathrm{NMR}{ }^{1} \mathrm{H}\left(\mathrm{CDCl}_{3}\right) \delta: 6.76$ (s, 2H, $\left.\mathrm{CH}=\right)$; 7.25-7.45 (m, 3H, H arom.); 7.77 (s, 1H, OH ); IR (KBr, $v_{\max }$, $\left.\mathrm{cm}^{-1}\right): 3241(\gamma \mathrm{OH}), 1683(\gamma \mathrm{C}=\mathrm{O}), 1587,1170,884,536$. 
TABLE-1

OXIDATION OF HYDROQUINONES INTO QUINONE WITH SUPPORTED METALATED PHTHALOCYANINES

2-Methylphenol

2-Hydroxy-1,4-naphthoquinone: Lawsone (4): Orange solid, yields: $79 \%$, m.p.: $194^{\circ} \mathrm{C}$ (lit.; 191-194 ${ }^{\circ} \mathrm{C}$ ) ${ }^{13} ; \mathrm{C}_{10} \mathrm{H}_{6} \mathrm{O}_{3}$, calcd. H $3.47 \%$ C $68.97 \%$; Found: H $3.53 \%$ C $68.92 \%$; UVvisible $\lambda_{\max } \log (\varepsilon)$ (dioxane $\left./ \mathrm{H}_{2} \mathrm{O}\right)$ nm: 276.3 (4.48), 334.3 (3.28); ${ }^{1} \mathrm{H} \mathrm{NMR}\left(\mathrm{CDCl}_{3}\right): \delta: 6.37$ (s, $\left.1 \mathrm{H}, \mathrm{OH}\right) ; 7.26$ (s, $1 \mathrm{H}, \mathrm{H}$ arom.); 7.25-8.14 (m, 4H, H arom); IR (KBr, $\left.v_{\max }, \mathrm{cm}^{-1}\right): 3166$ $(\gamma \mathrm{OH}), 1676(\gamma \mathrm{C}=\mathrm{O}), 1592,1170,874,668,536$.

2-Methyl-1,4-naphthoquinone : Menadione (5): Yellow solid, Yield: $80 \%$, m.p.: $104-105^{\circ} \mathrm{C}$ (lit. $105-107{ }^{\circ} \mathrm{C}$ ) ${ }^{13}$; $\mathrm{C}_{11} \mathrm{H}_{8} \mathrm{O}_{2}$, calcd. H $3.38 \%$ C $78.25 \%$, Found: $\mathrm{H} 4.42 \% \mathrm{C}$ $78.18 \%$; UV-Visible $\lambda_{\max } \log (\varepsilon)\left(\right.$ dioxane $\left./ \mathrm{H}_{2} \mathrm{O}\right) \mathrm{nm}: 264,1$ (4.18), 332.5 (3.36); ${ }^{1} \mathrm{H}$ NMR $\left(\mathrm{CDCl}_{3}\right): \delta: 2.21\left(\mathrm{~s}, 1 \mathrm{H}, \mathrm{CH}_{3}\right)$; 6.85 (s, 1H, H); 7.75-8.14 (m, 4H, H arom); IR (KBr, $\left.v_{\max }, \mathrm{cm}^{-1}\right)$ : 1732, 1668, $(\gamma \mathrm{C}=\mathrm{O}), 1593,1082,940,884,720,650$.

1,2,4,5-Tetracetoxynaphthalene (3a): Marron solid, Yield: $63 \%$, m.p.: $137-138{ }^{\circ} \mathrm{C}$; $\mathrm{NMR}{ }^{1} \mathrm{H}\left(\mathrm{CDCl}_{3}\right): \delta: 2.33$ (s, $\left.3 \mathrm{H}, \mathrm{OCOCH}_{3}\right) ; 2.35$ (s, 3H, $\left.\mathrm{OCOCH}_{3}\right) ; 2.40$ (s, 3H, $\mathrm{OCOCH}_{3}$ ); 2.42 (s, 3H, $\left.\mathrm{OCOCH}_{3}\right)$; 7.68-8.07 (m, 4H, H arom); IR (KBr, $\left.v_{\max }, \mathrm{cm}^{-1}\right): 3009(\gamma \mathrm{CH}$ arom. $), 1774\left(\gamma \mathrm{OCOCH}_{3}\right), 1762,1719$.

1,2,3,4-Tetracetoxynaphthalene (4a): Beige solid, Yield $66 \%$, m.p: $-140-143{ }^{\circ} \mathrm{C} ;{ }^{1} \mathrm{H}$ NMR $\left(\mathrm{CDCl}_{3}\right) \delta: 2.39$ (s, 6H, $\left.\mathrm{OCOCH}_{3}\right) ; 2.44$ (s, 6H, $\left.\mathrm{OCOCH}_{3}\right) ; 7.46-8.14$ (m, 4H, H arom); IR $\left(\mathrm{KBr}, \mathrm{v}_{\max }, \mathrm{cm}^{-1}\right): 3012(\gamma \mathrm{CH}$ arom $), 1760\left(\gamma \mathrm{OCOCH}_{3}\right)$, 1718; MS m/z (\%); 360 (M+2 24.46), 318 (3.41), 276 (16.38), 192 (100), 146 (11.95), 105 (23.55).

2-Methyl-1,3,4-triacetoxynaphthalene (5a): Beige solid, Yield: $59 \%$, m.p.: $148-150{ }^{\circ} \mathrm{C}$; $\mathrm{NMR}{ }^{1} \mathrm{H}\left(\mathrm{CDCl}_{3}\right): \delta$ : $2.16\left(\mathrm{~s}, 3 \mathrm{H}, \mathrm{CH}_{3}\right) ; 2.37\left(\mathrm{~s}, 3 \mathrm{H}, \mathrm{OCOCH}_{3}\right) ; 2.45(\mathrm{~s}, 3 \mathrm{H}$, $\left.\mathrm{OCOCH}_{3}\right) 7,2.49$ (s, 3H, $\left.\mathrm{OCOCH}_{3}\right)$ 7.48-7.76 (m, 4H, H arom); IR $\left(\mathrm{KBr}, v_{\max }, \mathrm{cm}^{-1}\right): 3000(\gamma \mathrm{CH}$ arom. $), 1774\left(\gamma \mathrm{OCOCH}_{3}\right)$, 1760; MS m/z (\%); $316\left(\mathrm{M}^{+} ; 39.13\right), 274$ (12.50), 233 (17.38), 174 (6.63), 115 (2.88).

2,5-Dihydroxy-1,4-naphthoquinone (3b): Yellow solid, Yields: $89 \%$, m.p.: $210^{\circ} \mathrm{C}$; UV-visible $\lambda_{\max } \log (\varepsilon)$ (dioxane/ $\left.\mathrm{H}_{2} \mathrm{O}\right) \mathrm{nm}: 279,3(4,68), 331,3(3,08) ;{ }^{1} \mathrm{H}$ NMR $\left(\mathrm{CDCl}_{3}\right): \delta$ : 6.39 (s, 1H, OH); 6.40 (s, 1H, OH); 7.18-8.01 (m, 5H, H arom); IR $\left(\mathrm{KBr}, v_{\max }, \mathrm{cm}^{-1}\right): 3168(\gamma \mathrm{OH}), 1679(\gamma \mathrm{C}=\mathrm{O}), 1591,1176$, $881,544$.

2,3-Dihydroxy-1,4-naphthoquinone (4b): Beige clear solid, yields: $91 \%$, m.p.: $201{ }^{\circ} \mathrm{C}$; UV-visible $\lambda_{\max } \log (\varepsilon)(\mathrm{di}-$ oxane/ $\left.\mathrm{H}_{2} \mathrm{O}\right) \mathrm{nm}: 289.3$ (4.77), 339.3 (3.27); ${ }^{1} \mathrm{H}$ NMR $\left(\mathrm{CDCl}_{3}\right)$ $\delta: 6.41(\mathrm{~s}, 1 \mathrm{H}, \mathrm{OH}) ; 6.42(\mathrm{~s}, 1 \mathrm{H}, \mathrm{OH}) ; 7.31-8.11(\mathrm{~d}, 4 \mathrm{H}, \mathrm{H}$ arom); IR $\left(\mathrm{KBr}, v_{\max }, \mathrm{cm}^{-1}\right): 3172(\gamma \mathrm{OH}), 1678(\gamma \mathrm{C}=\mathrm{O}), 1589$, 1174, 878, 536.
2-Hydroxy-3-methyl-1,4-naphthoquinone (5b): Yellow solid, Yields: $92 \%$, m.p.: $173-174^{\circ} \mathrm{C}$ (ether + hexane), $\mathrm{C}_{11} \mathrm{H}_{8} \mathrm{O}_{3}$ calcd. H $4.29 \%$ C 70.21; Found: H $4.35 \%$ C $70.08 \%$, UVvisible $\lambda_{\max } \log (\varepsilon)$ (dioxane/ $\left.\mathrm{H}_{2} \mathrm{O}\right) \mathrm{nm}: 271.3$ (4.44), 346.6 (3. 21); ${ }^{1} \mathrm{H} \mathrm{NMR}\left(\mathrm{CDCl}_{3}\right)$ : $\delta: 2.08\left(\mathrm{~s}, 1 \mathrm{H}, \mathrm{CH}_{3}\right) ; 6.42(\mathrm{~s}, 1 \mathrm{H}, \mathrm{OH})$; 7.29 (s, 1H, OH); 7.5-8.1 (m, 4H, H arom.); IR (KBr, $\left.v_{\max }, \mathrm{cm}^{-1}\right)$ : $3330(\gamma \mathrm{OH}), 1655(\gamma \mathrm{C}=\mathrm{O}), 1589,1174,878,536$.

\section{RESULTS AND DISCUSSION}

Oxidation of phenols and hydroquinones into quinones: The phenol oxidation products are used for the synthesis of natural products such as vitamins and their intermediates. Concerning the oxidation of phenols or hydroquinones into quinones numerous oxidants were described in the literature such as silver oxide ${ }^{14}$, ceric ammonium nitrate ${ }^{15}$.

In a preliminary study, we were inspired by the reaction of Elbs ${ }^{16}$ to access to hydroquinones by oxidation of phenols by sodium persulfate $\left(\mathrm{Na}_{2} \mathrm{~S}_{2} \mathrm{O}_{8}\right)$. We have tested the oxidation of hydroquinones into quinones by air catalyzed a metalated phthalocyanine $^{17}$ on the sheet of a montmorillonite K10. hydroquinones and substituted hydroquinones was easily oxidized at room temperature in quinones by using ( $\mathrm{Pc}[\mathrm{Co}] /$ K10) and air (1 atm), as indicated in (Scheme-II). Results obtained from different phenols were reported in Table-1.

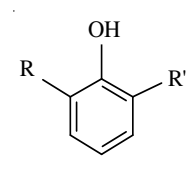

Phenol $\mathrm{R}=\mathrm{H}, \mathrm{R}^{\prime}=\mathrm{CH}_{3}$ $\mathrm{R}=\mathrm{R}^{\prime}=\mathrm{CH}_{3}$ $\mathrm{R}=\mathrm{R}^{\prime}=\mathrm{OMe}$

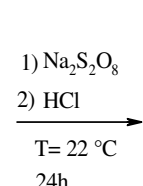

$24 \mathrm{~h}$<smiles>C1CC1</smiles>

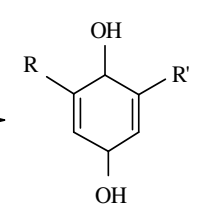

Hydroquinone

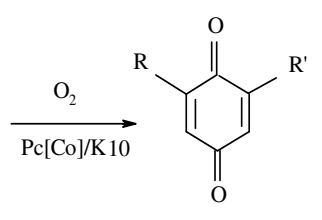

Quinone
Scheme-II: Oxidation of hydroquinones into quinones

The direct oxidation of phenols with oxygen in presence of supported metalled phthalocyanines as oxidant generally gave quinone at room temperature but the reaction is very slow and not selective.

We have also tested this type of reaction in naphthoquinone series. Many of naphthoquinone are natural products with interesting biological properties. The catalytic system $[\mathrm{Pc}(\mathrm{Co}) / \mathrm{K} 10]$ in presence of pure oxygen oxidises easily the 1,5-dihydroxynaphthalene in Juglone (yield $87 \%$ ). (This latter 


\begin{tabular}{|c|c|c|c|c|c|}
\hline \multicolumn{6}{|c|}{$\begin{array}{c}\text { TABLE-2 } \\
\text { OXIDATION OF HYDROXYNAPHTHALENE }\end{array}$} \\
\hline Hydroxynaphthalene & Oxidation catalysts & Naphthoquinone & m.p. $\left({ }^{\circ} \mathrm{C}\right)$ & UV-Visible $\lambda_{\max } \mathrm{nm}$ & Yield (\%) \\
\hline 1,5-Dihydroxynaphthalene & $\mathrm{Pc}[\mathrm{Co}] / \mathrm{K} 10$ & $\begin{array}{l}\mathrm{OH} \quad \mathrm{b} \\
\text { Juglone } 3\end{array}$ & 159 & 331,1 & 87 \\
\hline 1,3-Dihydroxynaphthalene & $\mathrm{Pc}[\mathrm{Co}] / \mathrm{K} 10$ & Lawsone 4 & 194 & 334,3 & 79 \\
\hline 2-Methyl-1,4-Dihydroxy naphthalene & $\mathrm{Pc}[\mathrm{Co}] / \mathrm{K} 10$ & Menadione 5 & 103 & 332,5 & 80 \\
\hline
\end{tabular}

TABLE-3

ACETOXYLATION OF JUGLONE AT $20^{\circ} \mathrm{C}$

\begin{tabular}{ccccccc}
\hline Catalyst & Aspect & Hammet: Ho & Experimental & m.p. $\left({ }^{\circ} \mathrm{C}\right)$ & IR vester $\left(\mathrm{cm}^{-1}\right)$ & Yield \\
\hline $\mathrm{ClSO}_{3} \mathrm{H}$ & Liquid & $-13,80$ & $20{ }^{\circ} \mathrm{C}, 20 \mathrm{~h}$ & 148 & 1773 & $55 \%$ \\
$\mathrm{H}^{+}$-DAY & Solid & - & $20^{\circ} \mathrm{C}, 48 \mathrm{~h}$ & 149 & 1772 & $56 \%$ \\
$\mathrm{H}^{+}-\mathrm{ZSM} 5$ & Solid & - & $20{ }^{\circ} \mathrm{C}, 48 \mathrm{~h}$ & 148 & 1776 & $54 \%$ \\
$\mathrm{H}_{3} \mathrm{PW}_{12} \mathrm{O}_{40}$ & Solid & $-13,6$ & $20^{\circ} \mathrm{C}, 48 \mathrm{~h}$ & 149 & -1773 & $61 \%$ \\
$\mathrm{H}_{3} \mathrm{PMo}_{12} \mathrm{O}_{40}$ & Solid & - & $20{ }^{\circ} \mathrm{C}, 48 \mathrm{~h}$ & - & - & - \\
$\mathrm{H}_{4} \mathrm{SiW}_{12} \mathrm{O}_{40}$ & Solid & - & $20{ }^{\circ} \mathrm{C}, 48 \mathrm{~h}$ & 152 & 1774 & $63 \%$ \\
\hline
\end{tabular}

is used as alimentary stain for soft drinks). The total oxidation was about $6 \mathrm{~h}$ at room temperature. Results obtained from different phenols were reported in Table-2.

Thiele-winter reaction: The 5-Hydroxynaphthoquinone (3) treated with acetic anhydride in the presence of catalyst converts into the 1,2,4,5-tetracetoxynaphthalene (3a) (yield $63 \%$ ).

We have studied this reaction with strong acids. chlorosulfonique acid $\left(\mathrm{H}^{\circ}=-13.80\right)$ and perchloric $\operatorname{acid}^{18}\left(\mathrm{H}^{\circ}=\right.$ -10.31) led to the desired product.

The reaction with solid superacids show a high Brônsted acidity and it was lower than with homogeny phase.

Heteropolyacids (HPAs also called polyoxometalates) are catalysts of great interest ${ }^{19}$. The display has a very high Brônsted acidity close to superacids. It is decided to test three heteropolyacids $\left(\mathrm{H}_{3} \mathrm{PW}_{12} \mathrm{O}_{40}(\mathrm{PW}), \mathrm{H}_{4} \mathrm{SiW}_{12} \mathrm{O}_{40}(\mathrm{SiW})\right.$ and $\mathrm{H}_{3} \mathrm{PMo}_{12} \mathrm{O}_{40}(\mathrm{PMO})$. The $(\mathrm{SiW})$ provide the product with a yield of $63 \%$ whereas a yield of $61 \%$ was achieved with the $(\mathrm{PW})$. It has been noticed that the (SiW) appeared a better catalyst than the (PW). Explanation could be assigned to the higher ratio of number of protons in $(\mathrm{SiW})^{20}$.

Zeolites with high $\mathrm{Si}-\mathrm{Al}$ ration (15-20) are known to posses strongly acidic sites 10 . Two acid zeolites $\left(\mathrm{H}^{+}\right.$-ZSM5 and $\mathrm{H}^{+}$-DAY) were also tested successfully. Zeolites can be reused without loss of activity when the reaction is carried out at room temperature. No poisoning by tar formation was observed with ZSM5 or DAY. With solid catalysts like zeolite, the Juglone is too wide to enter the pores of ZSM5 and the reaction took place on the surface of zeolite.

We have noticed that no product (3a) was obtained with the $\mathrm{H}_{3} \mathrm{PMo}_{12} \mathrm{O}_{40}$ (PMO). The reaction medium colour changed, from green to deep blue, roving the reduction of PMO. The result with (PMO) is not surprising owing to its high redox potential resulting from the presence of molybdenum atom. Results of acetoxylation of Juglone by acetic anhydride obtained from different acids catalysts were reported in Table-3.

The kinetics of the reaction was monitored hourly by visible spectroscopy ultrat purple. The kinetic of menadione transformation (bleaching) was monitored at $333 \mathrm{~nm}$, which is the maximum point of menadione (5) (The vitamin K3 carrier). There is (Scheme-III) changes in the UV/visible spectrum in the presence of $\mathrm{ClSO}_{3} \mathrm{H}$.

The kinetic of menadione transformation (bleaching) depends on acidity of catalyst. It seems that the limiting step of the Thiele-Winter reaction is the protonation of the quinine.

The 1,2,4,5-tetracetoxynaphthalene (3a) was easily transformed into (3b) by saponification basic and oxidation with potassium hydroxide $(\mathrm{KOH})$ in methanol $\left(\mathrm{CH}_{3} \mathrm{OH}\right)$ in presence of air at room temperature. The yield of 2,5-dihydroxy-1,4-

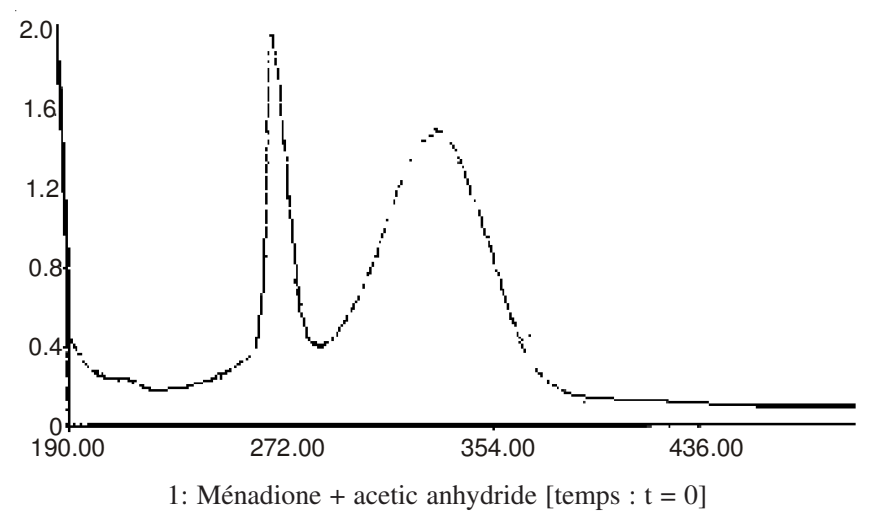


TABLE-4

SOLID ACID AS CATALYST FOR OXIDATION BY MOLECULAR OXYGEN. SYNTHESIS OF HYDROXYNAPHTHOQUINONES

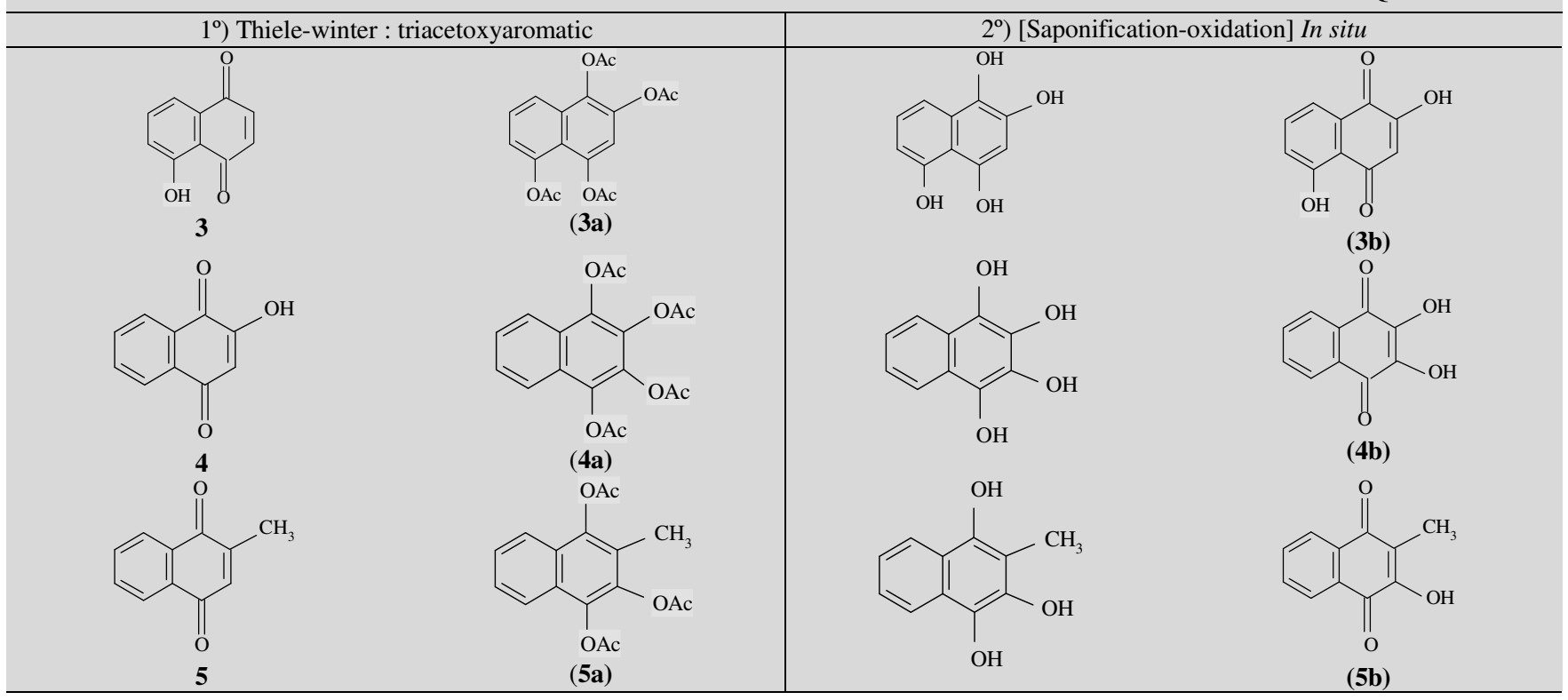

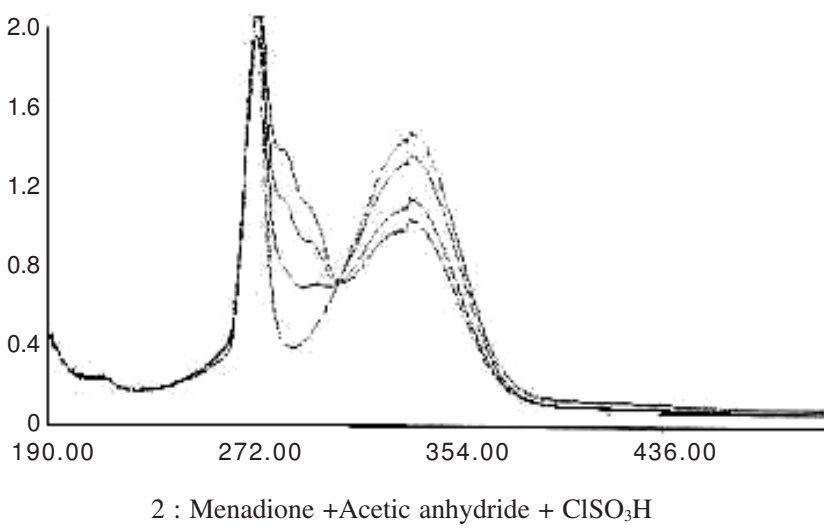

Scheme-III: Evolution of UV/visible spectrum in the presence of $\mathrm{ClSO}_{3} \mathrm{H}$

naphthoquinone from (3a) is good (89\%). The results obtained from the two steps sequence (triacetoxyaromatic and saponification-oxidation in situ) were reported in Table-4.

\section{Conclusion}

In conclusion it appears that chlorosulfonic acid is the most effective acid catalyst found for the acetoxylation reaction of juglone under homogeneous conditions. Zeolites $\left(\mathrm{DAY}-\mathrm{H}^{+}\right)$ heteropolyacids $\left(\mathrm{H}_{3} \mathrm{PMo}_{12} \mathrm{O}_{40}\right)$ can easily catalyze the ThieleWinter reaction. This work represents the first exemple of catalysis of this reaction by solid acids. The sequence of the two steps (acetoxylation, saponification-oxidation) constitutes a new synthesis of hydroxynaphthoquinones from hydroquinones.

\section{REFERENCES}

1. J.F.W. McOmie and J.M. Blatchey, Org. React., 19, 199 (1972).

2. S. Spyroudis, Molecules, 5, 1291 (2000).

3. A.M. Lira, A.A.S. Araújo, I.D.J. Basílio, B.L.L. Santos, D.P. Santana and R.O. Macedo, Thermochim. Acta, 457, 1 (2007).

4. R. Sauriasari and K. Ogino, Toxicology, 235, 103 (2007); in ed.: M. Windholz, The Merck Index; Merck and Co, Rahway, USA, edn. 12 (1993).

5. A. Combes, Bull. Soc. Chim., 1, 800 (1907); C.J. Soderquist, J. Chem., 50, 782 (1973).

6. J.J. Kessl and N.V. Moskalev, Biochim. Biophys. Acta, 1767, 319 (2007).

7. M.B. Teimouri and H.R. Khavasi, Tetrahedron, 63, 10269 (2007); C. Valente, Med. Bioorg., 15, 5340 (2007).

8. J. Thiele, Ber., 31, 1247 (1898).

9. J. Thiele and E. Winter, Ann., 311, 341 (1900).

10. H. Burton and P.F.G. Praill, J. Chem. Soc., 755 (1952).

11. R.J. Gillepsi, Can. Chem. Educ., 4, 9 (1969).

12. Aldrich-Chemie, France (1995)

13. M. Windholz, éd., The Merck Index; Merck and Co, Rahway, USA, edn 12 (1993).

14. J.K. Muchie and J.A. Miller, Synthesis, 824 (1981).

15. K.S. Kochlar, B.S. Bal and R.P. Deshpande, J. Org. Chem., 48, 1785 (1983).

16. K.J. Elbs, Prakt. Chem., 48, 179 (1993).

17. D. Villemin and M. Hammadi, Actes of $3^{\text {th }}$ Colloque Franco-Magrébin; 611 (1996).

18. N.F. Hull and J.B. Conant, J. Am. Chem. Soc., 49, 3047 (1927): G.A. Olah, G.K.S. Pradash and J. Sommer, Superacids, Wiley, New York (1985); G.A. Olah, Angew. Chem. Int. Ed. Engl., 32, 727 (1993); D. Villemin and M. Richard, React. Kinet. Catal. Lett., 52, 355 (1994).

19. Y. Izumi, K. Urabe and M. Onaka, in: Zeolite, Clay and Heteropolyacid, in Organic Reactions, Tokyo-kodansha-Weinheim, VCHI, pp. 100-120 (1992); P. Dupont and F. Lefebvre, J. Mol. Catal. A, 114, 299 (1996).

20. Y. Izumi and K. Matsuo, J. Mol. Catal., 18, 299 (1983). 